\title{
THE MITHRAIC PRAESEPIA AS DINING BEDS
}

\begin{abstract}
Summary: A mithraeum always has long benches, which were called praesepiae, "places where cattle are fed in a stall" (CIMRM 233). The name is inappropriate for a dining room, which was usually called, instead, triclinium. Mithraeum is the current modern name, whereas the ancients called it spelaeum, antrum, templum. Another important name was Leonteum, which was not a separate cultic place for Leones only, because Porphyry states that the members of a Mithraic community were the Leones and the servants were called Korakes, the Ravens (Porphyr. de abst. 4. 16). The Mithraic menu apparently consisted of meat rather than of vegetables, even though one should take into account the fact that bones are better preserved than vegetables in an archaeological site, and therefore they are often published, whereas vegetal remains had never been investigated by means of chemical analyses. Lions are notoriously carnivorous and the praesepiae had to be filled with meat for the Leones.

The initiation of Leones was supposed to be dry and fiery (Tert. Adv. Marcionem I 13), and we are also told that the Mithraic Leones avoided water for their purifications and washed their hands with honey (Porph. De antro 15-16). Moreover, a lion and a snake are often depicted on Mithraic reliefs as going to drink from a crater. It is possible to get some information from those facts about what Leones were used to drinking during their symposia: they were thirsty but their drink could not be water, but eventually, wine was permitted. Iustin. Apol. I 66 speaks of a cup of water, but only to mention some ritual acts during initiations and not during symposia.
\end{abstract}

Key words: Mithraism, Roman religion, Mithraic diet

A passage in Porphyry says that, among the Mithraists, there were participants called Leones, and servants called Korakes, i.e. Corvi:

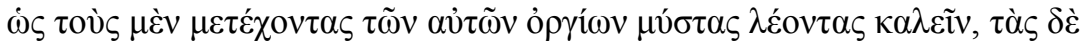

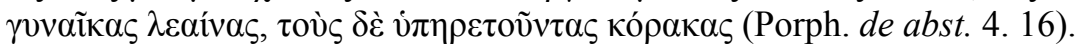

"They denominate the males who participate in the same mysteries 'Lions', but the females 'Lionesses', and those who are servants 'Crows'."

This passage is probably imprecise, because the Lionesses are otherwise unknown in the Mithraea, and, in a subsequent passage, Porphyry adds that the Mithraic women 
were called hyenas, and that there were also eagles and hawks, but no testimony from the Mithraea or from other sources confirms those statements.

The Greek philosopher underlines the importance of the initiation into the grade of Leo, and adds the following:

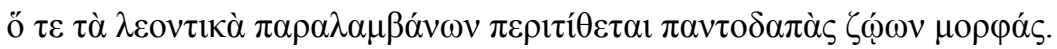

"He who is initiated in the Leontic mysteries puts on many different forms of animals."1

In this paper I will underscore that Porphyry was definitely correct in stating that members of the Mithraic communities were the Leones and that their ceremonies were conceived of as meetings for animals.

An inscription from the Aldobrandini Mithraeum at Ostia says:

Deum vetusta religione /

in velo formatum et umore obnubil

latum marmoreum cum /

throno omnibusq(ue) ornamentis /

a solo omni impendio suo fecit /

Sex(tus) Pompeius Maximus pater /

q(uod) s(upra) s(criptum) est I

et praesepia marmoravit p(edes) LXVIII idem s(ua) p(ecunia).

"The Pater Sextus Pompeius Maximus (whose name is written above) paid out of his own pocket for the marble (statue of the) god, standing on the floor, with the throne, all his decorations, and he coated with marble the stalls for a length of 68 feet. The god, in accord with the old devotion, was (previously) depicted on a veil but it was fading because of the humidity."

These praesepia could not have been a fence, as Herrmann Dessau supposed, ${ }^{2}$ because a fence could not be coated with marble, but they were, instead, the benches, whose length was of about $20 \mathrm{~m}$, as Becatti ${ }^{3}$ and Vermaseren ${ }^{4}$ supposed. A mithraeum always has long benches, but praesepia, "places where cattle are fed in a stall", 5 was an inappropriate name for a dining room, which was usually called a triclinium. Mithraeum is the current modern name, whereas the ancients called it spelaeum, antrum, templum. Another important name was Leonteum. An inscription from Carsulae

\footnotetext{
${ }^{1}$ On the mistakes in this Porphyrian passage, see TURCAN, R.: Une aporie de la tradition litteraire sur le « Lion » mithriaque. In BONNET, C. - PIRENNE-DELFORGE, V. - PRAET, D. (eds): Les religions orientales dans le monde grec et romain: cent ans après Cumont (1906-2006). Bilan historique et historiographique. Colloque Rome, 16-18 November 2006. Brussels-Rome 2009, 429-448 = Recherches mithriaques, 419-442.

${ }^{2}$ CIL XIV, Suppl. 1, 220.

${ }^{3}$ BeCATtI, G.: Scavi di Ostia. Vol. II: I mitrei. Roma 1954, 40.

${ }^{4}$ CIMRM I 120.

${ }^{5}$ CIL XIV $4314=$ CIMRM 233. The addition vetusta(te), proposed by Vermaseren, is improbable.
} 
(Umbria) testifies to a Leonteum, ${ }^{6}$ which was not a separate cultic place for Leones only, such as a chapel or a room for the lion-headed Aion, because the inscription states that it was a temple built from the ground at the Leones' expense. ${ }^{7}$

The Leonteion, the Pater, and the Leo were peculiar institutions of Mithraism and they are mentioned in a fragmentary text written on a 4th century CE papyrus from Hermupolis. Some words in this text have been compared by its editor to those associated with Mithraic cults, ${ }^{8}$ but this text raises doubts and problems. ${ }^{9}$ It is improbable, however, that an Egyptian cult to a local lion-god would have had some devotees who became Leones by means of a Pater, and that these devotees had a Leonteion at their disposal.

The Mithraeum of Santa Prisca (built under Commodus) in Rome, was just such a place for Leones, as its inscriptions and frescoes prove. ${ }^{10}$ Besides, the title of pater Leonum is documented. ${ }^{11}$ A certain Marcellinus is styled Leo antistes ("Lion, the priest"). ${ }^{12}$ The sources also speak relatively frequently of Leones, ${ }^{13}$ and Tertullian knew that the Leones were used to discussing the dry and fiery features of their initiation. ${ }^{14}$

The grade of the Leo was the final step in a series of initiations, after which one was supposed to be "brought to perfection". This is, in fact, the meaning of consummati. A painted inscription in the Mithraeum of Santa Prisca says:

accipe thuricremos Pater accipe sancte leones /

per quos thura damus per quos consumimur ipsi.

"Receive, oh holy Pater, receive the Leones, who burn incense, thanks to whom we give incense and thanks to whom we ourselves are brought to perfection."15

${ }^{6}$ CiOtTI, U.: Due iscrizioni mitriache inedite. In DE BOER, M. - EdRIDGE, T. A.: Hommage à Maarten J. Vermaseren [EPRO 68]. Vol. I. Leiden 1978, 233-246, in part. 236: Leonteum, cum signo et cetero cultu exornatum ex permissu sanctissimi ordinis, ex pec(unia) sua a solo fecerunt leones, consummati ab Egnatio Repara[t]o sacerdote legit(imo) et collatore ("the Leonteum has been built, with the statue and the cultic decoration, with the permission of the holy council (i.e. the Decuriones), by the Leones, brought to perfection by Egnatio Reparato, legitimate priest and contributor"). Cf. BRASHEAR, W. M.: A Mithraic Catechism from Egypt <P.Berol. 21196>. Vienna 1992; SFAMENI GASPARRO, G.: Il mitraismo: una struttura religiosa fra 'tradizione' e 'invenzione'. In BIANCHI, U. (ed.): Mysteria Mithrae. Leiden 1979, 349-384.

${ }^{7}$ RUBIO RIVERA, R.: El Leonteum de la inscriptiòn de San Gemini: sede de los Leones mitriacos. In Homenaje a José Maria Blàzquez. III: Historia de Roma. Madrid 1996, 320-329, where previous interpretations are mentioned.

${ }^{8}$ BRASHEAR (n. 6).

${ }^{9}$ TURCAN, R.: Un “catéchisme" mithriaque? CRAI 1992, 544-564.

${ }^{10}$ VERMASEREN, M. J. - VAN ESSEN, C. C.: The Excavation in the Mithraeum of the Church of Santa Prisca in Rome. Leiden 1965, 148-150, 161-162, 165-167, 224-239; CIMRM 481-487.

${ }^{11}$ CIL XI $5737=$ ILS $4215=$ CIMRM I $688=A E 2006,243$.

12 CIMRM 367.

${ }^{13}$ Cf. AlOE SPADA, C.: Il 'leo' nella gerarchia dei gradi mitriaci. In Mysteria Mithrae (n. 6) 639648; Clauss, M.: Die sieben Grade des Mithras-Kultes. ZPE 82 (1990) 183-194, in part. 186.

${ }^{14}$ Tert. Adv. Marcionem I 13: sicut aridae et ardentis naturae sacramenta leones Mithrae philosophantur.

${ }^{15}$ CIMRM 485. It is probable that consumimur was used instead of consummamur (i.e. consummati sumus): "we are brought to perfection, we are perfectly instructed"; see VOLLGRAFF, W.: Le rôle des 


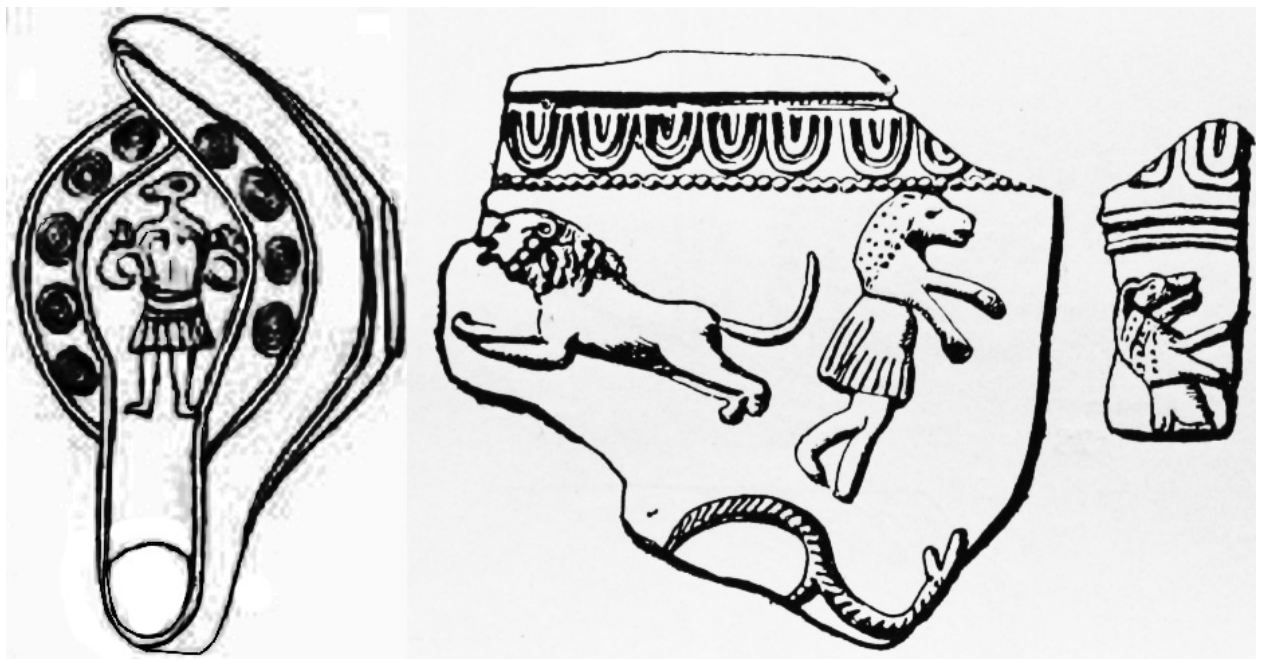

Lamp from Aquileia depicting a man with the mask of a crow (from MASELLI SCOTTI [n. 18]).

Fragments of a vase from Ittenweiler depicting a man with the mask of a lion (from GORDON [n. 18])

This interpretation is confirmed by this sentence in an inscription from Carsulae:

leones, consummati ab Egnatio Repara[t]o sacerdote. ${ }^{16}$

Leones who were brought to perfection by the priest Egnatius Reparatus.

Now we take again into account Porphyry's statement, that "he who is initiated in the Leontic mysteries puts on many different forms of animals".

The Konijc relief ${ }^{17}$ shows a Leo and a Corvus, with their animal masks, as waiters at the dinner of Mithras and Sol, and this scene is supposed to allude also to the cultic dinners in the mithraea because we can see many images of waiters wearing masks corresponding to the Crow, i.e. the Korax/Corvus, and initiates wearing a mask of a lion are also depicted (fig.). ${ }^{18}$ The difference between the banquet of Mithras and

Lions dans la communauté mithriaque. In Hommages à L. Herrmann [Coll. Latomus 44]. Brussels 1960, 777-785, in part. 785; TuRCAN, R.: La Physica Ratio des 'Lions' mithriaques Tert., Marc. 1,13,5. In TERnES, CH. M. (ed.): Foi, raison, verbe: mélanges in honorem Julien Ries. Luxembourg 1993, 239250, in part. 248-249. CLAUSS (n. 13) 186 says that the degree of the Leo was a sort of "Zwischenstation" (an intermediate stop) in the initiates' career.

${ }^{16}$ CIOTTI (n. 6) 236 (with translation: “consecrated”).

${ }^{17}$ CIMRM 1896.

${ }^{18}$ Ravens as waiters: CIMRM 42.13 (Dura) and 397 (Castra Praetoria, Rome); SCHWERTHEIM, E.: Die Denkmäler orientalischer Gottheiten im römischen Deutschland [EPRO 40]. Leiden 1974, Mainz 94; other images of men with a raven's mask: MASELLi SCOTTI, F.: Presenze di culto mitraico nell'alto Adriatico. In Le regioni di Aquileia e Spalato in epoca romana. Convegno in Castello di Udine, 4 Apr. 2006. Treviso 2007, 81-106 (http://www.mitraismo.info/wp-content/uploads/franca\%20scotti\%20maselli.pdf) 
Sol and that of the initiates can account for the role of the Leones either as waiters or as banqueters.

The special role of Leones and Corvi is confirmed also by a passage from a work ascribed to St Augustine where the author argues against the mysteries of Mithras with the following words:

Alii autem sicut aves alas percutiunt vocem coracis imitantes; alteri vero leonum more fremunt.

Some participants flap their wings like birds, imitating the call of the raven; others roar like lions. ${ }^{19}$

Now we can understand why the benches are called praesepiae: the banqueters imitated some animals, and especially the ravens and the lions. These are the only initiatory grades called after the name of animals, and they were crucial in the career of a Mithraist, for they represented the beginning and the perfection, respectively.

Lions are notoriously carnivorous and the praesepiae had to be filled with meat for the Leones. Also the Mithraic ravens were supposed to eat, or to eat especially meat, for a relief from Poetovio shows Mithras and Sol close to an altar, holding skewers at which a raven is nibbling. ${ }^{20}$

The Mithraic menu apparently consisted of meat rather than of vegetables, even though one should take into account the fact that bones are better preserved than vegetables in an archaeological site, and therefore they were often published, whereas vegetal remains had never been investigated by means of chemical and paleobotanic analyses. Even if we take into account this lack of documentation, the documents we have gathered here suffice to show that the Mithraic communities were mostly composed of Leones, whose menu should have consisted of meat, or, at least, mostly of meat.

The initiation of Leones was supposed to be dry and fiery (Tert. Adv. Marcionem I 13), and we are also told that the Mithraic Leones avoided water for their purifications and washed their hands with honey (Porph. De antro 15-16). Moreover, a lion and a snake are often depicted on Mithraic reliefs as going to drink from a crater. It is possible to get some information from those facts about what Leones were used to drinking during their symposia: they were thirsty but their drink could not be water, but, eventually, it included wine. Iustin. Apol. I 66 speaks of a cup of water, but only to mention some rituals associated with the initiations and not during symposia.

(lamps from Aquileia whose Mithraic character is not yet completely ascertained); L. SCHWINDEN in Imperium der Götter: Isis - Mithras - Christus: Kulte und Religionen im Römischen Reich 258, no. 175 (vase from Trier). On images of Leones with their mask, see GORDON, R. L.: Ritual and Hierarchy in the Mysteries of Mithras. ARYS 4 (2001) 245-273, in part. 234, n. 30. Souter).

${ }^{19}$ Ps.-Augustin. (also called Ambrosiaster), Quaest. vet. et novi Test. 114. 11 (CSEL 50, 308

${ }^{20}$ CIMRM 1584. 
To conclude, we remember that many sources and inscriptions suggest a scenario of Mithraic initiates who imitated the behavior of some animals, and, in particular, of lions and ravens. As the Leones and the Korakes were more numerous than the others, the mithraea were called Leonteia and compared with stables.

Attilio Mastrocinque

Department of Cultures and Civilisations

University of Verona

Italy 